\title{
EXHIBITS AT THE Ateneo Art Gallery JANUARY-DECEMBER 2013
}

Tuloy Po Kayo, Welcome!

David Medalla

November 27, 2012-January 30, 2013

You Have Every Right

Maria Cruz, Lizza May David, Kiri Dalena, Claudia del Fierro, Annika Eriksson,

Tracey Moffatt, Lilibeth Cuenca Rasmussen

February 16-April 20, 2013

Multiplicity: The Art of Fine Prints

Selections from the permanent collection

June-August 2013

Ateneo Art Awards 2004-2013: A Retrospective

Geraldine Javier, Louie Cordero, Jason Oliveria, Ronald Ventura, Eric Zamuco,

Annie Cabigting, Mideo Cruz, Poklong Anading, Maya Muñoz, MM Yu,

Wawi Navarroza, Lyle Buencamino, Kawayan de Guia, Marina Cruz, Patricia

Eustaquio, Kiri Dalena, Leeroy New, Pow Martinez, Leslie de Chavez, Mark

Salvatus, Bemboldela Cruz, Maria Taniguchi, Martha Atienza, Riel Hilario

September 16-December 10, 2013

Marking Time: 2013 Ateneo Art Awards

Pio Abad, Allan Balisi, Charles Buenconsejo, Zean Cabangis, Buen Calubayan, Joey Cobcobo, Nikki Luna, Joven Mansit, Raffy T. Napay, Leeroy New, Ryan Villamael

September 16-December 10, 2013 
The year opened with David Medalla's exhibit, entitled Tuloy Po Kayo, Welcome! (November 27, 2012-January 30, 2013). It was his first show in the Philippines in more than thirty years. At the entrance to the exhibition were blown up photographs of significant times in Medalla's life. Medalla painted whimsical portraits of expatriates that in his eyes contributed to Philippine culture: the American anthropologist H. Otley Bayer, Spanish poet Jaime Gil de Biedma, Mr. Po of Popular Bookstore, the Finnish beauty queen Armi Kuusella, and the American Journalist Bessie Hackett. There were also murals recalling Filipino children's games and ditties, which Medalla worked on for the duration of the exhibition. His presence in the exhibition space allowed students and visitors the opportunity to chat with him and watch him work.

Medalla is a legend because of his more ephemeral works. He is a pioneer of kinetic and earth art, as well as participation, conceptual, and performance art. $\mathrm{He}$ is capable of both impromptu performances and elaborately planned scenarios that are spectacles to be watched and events to be joined. A video showed clips of his performances from all over the world. The video includes footage that Medalla and long-time collaborator Adam Nankervis took of grass-cutters in the grounds of Ateneo. During his residency in Ateneo the year prior to his exhibit, he was awakened very early each morning by the din of the grass cutters. What would have been an annoyance to most became the subject of a new artwork for Medalla. The movements of the grass-cutters were synchronized and choreographed into a beautiful performance.

Sand paintings, made especially for the exhibit, were created with sand-filled PVC pipes. As the pipes were rolled onto wooden panels, Medalla tapped them to coax the sand out. The rhythmic thumping was almost meditative in its regularity. The sand that oozed out imprinted the plywood with repeated patterns. The relief works, which straddle printmaking, painting, and kinetic art, are truly innovative pieces that attest to the enduring creativity of David Medalla.

The exhibition entitled You Have Every Right (February 16-April 20, 2013) brought together the works of seven female artists from all over the globe whose practices reflect upon the individual's place in society, how people (and animals) behave in certain situations, and how experiences and interactions are remembered, recorded, and reinterpreted.

For her piece The Great Good Place, Swedish artist Annika Eriksson recorded a feline congregation in Istanbul. It is a four-minute piece that shows cats gathering on a carpet that they have appropriated as their territory and their reactions to other cats that try to join the community. Tracey Moffatt's Love is an engaging twenty-one minute video montage "about the ecstasy and miseries of love affairs."

The works of Moffat and Erickson were selected by exhibition curator Lian Ladia from their existing bodies of work, but the other featured artists created 
new work in response to Ladia's invitation. Lilibeth Cuenca Rasmussen's Gaia \# 2 A Mother Earth Ritual, The Philippines was the second part of a ritual she created to help her deal with being a child of two cultures (Manila and Denmark). The two multi-sensory performances that she called "nullification rituals" involved the participation of her daughter and father in Gaia \#1 and her mother in Gaia \# 2. The audience was invited to join in by eating the watermelon slices offered to them by the three Rasmussen women. What remained in the museum was an installation of rocks from Mount Pinatubo, sampaguita petals, leaves, coconut shells, the interconnected costumes worn by the artist, her mother, and her daughter, and photos of the performance. Maria Cruz's Inner Noise was inspired by her memory of the Filipino film Nympha, considered very risqué and quite scandalous when it was released in 1971. She explored ideas of hysteria and sexuality, writing out lines from the film in block letters and a color palette limited to red, black and white.

Claudia del Fierro, Kiri Dalena, and Lizza May David played with notions of "archive." Del Fierro, a Chilean artist based in Sweden, took inspiration from the Ateneo Library of Women's Writings for her video installation Artefacto para remediar el registro (Device to remedy the record). Contemplating the idea of an archive as a repository of records and documents, she presented a two-screen video installation that juxtaposed footage from the quiet, organized, and highly specialized archive with video recordings of Philippine street life as seen from a moving tricycle, which could be considered archiving of a very different nature. Del Fierro built the walls of the projection room out of scrap materials. The structure, in finding new use for materials considered disposable by others, lent further cohesiveness to the project.

Dalena's Save Messages are an archive of another sort. During Typhoon Ondoy, Dalena monitored cries for help that came in via text, public discussion boards, and social media. She helped coordinate rescue operations by arranging the messages geographically and monitoring which ones had been responded to. She transformed this file into a sparse video of black text on a white background, projected onto a white wall. It is a reminder of the chaos and devastation that resulted from Ondoy and the desperation that led people to call out for help through whatever channels were available. It invites us to consider how during times of crisis, people are able to go beyond themselves and provide assistance to others.

For The Incomplete Project, David engaged with the Ateneo Art Gallery's collection of Philippine modern art. The result was a mural that incorporated the most recognizable images of the museum's modern art collection as well as a set of sketches from the concurrent exhibit, In the Eye of Modernity: Selections from the Ateneo Art Gallery Permanent Collection.

The mid-year exhibition, called Multiplicity: The Art of Fine Prints (JuneAugust, 2013), showcased selections from the Ateneo's collection of fine prints and drawings. 
The exhibition was designed to give people an orientation to intaglio (engraving, etching, aquatint, drypoint, collography, mezzotint), relief (embossing), serigraphy, and lithography. Among the works exhibited were Rembrandt Van Rijn's etching Descent from the Cross (1654), Francisco Goya's nineteenth century etching and aquatint Loyalty, Edouard Manet's etching Boy Blowing Bubbles (1869), Henri ToulouseLautrec's lithograph Madame Rejane, and Ben Shahn's screenprint Triple Dip.

For the final quarter of 2013, the Art Gallery celebrated the tenth anniversary of the Ateneo Art Awards (September 16-December 10). A survey of the winning works of the past decade revealed the varied techniques contemporary artists used to give visual form to their myriad concerns. On one end of the spectrum are Maria Taniguchi's meditations on form, Untitled (Mirrors) and Untitled (Celestial Motors), and on the opposite end are Pow Martinez's brightly colored canvasses featuring basketball teams and family portraits.

Strong artists dominated the entrance to the Retrospective. Eric Zamuco's Spring and White had wire coils and plastic filaments encased in plexiglass panels. These forms mutate according to the combination of light and shadow. On the floor was Poklong Anading's Fallen Map, an installation of rubble painted in geometric and patchwork patterns. Then there was Kawayan de Guia's Bomba, "mirror balls" in the shape of airplane bombs. Annie Cabigting's installation, Tearing into Pieces, was composed of dozens of small paintings in the shape of an art critic taking notes. The detail of a historical art photograph enlarged over forty-eight canvases filled a wall in homage to a 1977 artwork by Roberto Chabet. A couple of steps into the gallery revealed Ronald Ventura's masterful draftsmanship in Insecured, a graphite on marble resin work of a squatting naked man wearing a dog mask, Marina Cruz's Embroidered Landscape of My Mother's Life, a large photo on canvas of the artist's mother's dress onto which she had embroidered scenes and symbols of her life, and Kawayan de Guia's mixed media portraits of people that had influenced his life.

Artworks in the exhibition were grouped together according to the year they won, beginning with 2004 winner Geraldine Javier's eerie black and grey painting Body of a Fallen Father, and video documentation of Jason Oiveria's and Louie Cordero's awardwinning exhibits. Another alcove featured Maya Muñoz's four-paneled portrait With Love and Squalor, Poklong Anading's Anonymity lightboxes, the documentation of Mideo Cruz's CCP performance Banquet, and a series of photobooks from MM Yu's show Thoughts Collected, Recollected. In another room, theatrical photographs from Wawi Navarroza's exhibition, Saturnine: A Collection of Portraits, Creatures, Glass and Shadow, were on view across from Lyle Buencamino's Observations on Potato and Tomato, a black and white portrait of himself with his father.

Many of the artworks invited the viewer to question social and political structures, such as Leslie de Chavez's Banana Republic, Kiri Dalena's Erased Slogans, 
and Bemboldela Cruz's still lifes of innocuous household items that turned out to be bomb-making ingredients. Others emerged from actual interactions with the community. Martha Atienza immersed herself in the life of seamen and fishermen from her hometown of Madridejos for her three screen projection Gilubong ang Akon Pusod sa Dagat. Mark Salvatus's installation of plastic plants seen through a hole in the wall and sticker mural of a prison tag was inspired by his work with prisoners. Other artists conjured up imaginary creatures, such as Leeroy New's alien in Terratoma II (War of the Worlds), Riel Hilario's half-dog, half-woman sculpture Perro Amoroso, and Patricia Eustaquio's Arteria Axilliaris, a ceramic sculpture of a white violin torn open to reveal a heart and veins.

The eleven finalists of the 2013 Ateneo Art Awards had their own special exhibit, Marking Time. Pio Abad's work traverses both the historical and the personal with his father's photos of Pyongyang as the starting point for an investigation into the idea of mass games as a spectacle that transforms people into pixels of a picture. He imprinted imagery found on brochures and posters from his father's Pyongyang trip on a luxurious silk scarf. This adds another layer to the possible readings of his work-historical events brought into the realm of luxury goods, available for purchase and consumption.

The otherworldly is decidedly the realm of Leeroy New's Monstrosities. Creatures from his imagination come to life in plastic, neon, plant-animal amalgams, a fourlegged black creature with a mouth but no face and spikes all over its body. Allan Balisi's monochromatic oil and graphite paintings of images from horror and sci-fi films, such as the The Last House on the Left and Darren Ornofsy's Pi, have an eerie, dreamlike quality about them and leave the viewer curious, wanting to know more about his imagined worlds.

Nikki Luna had her feet firmly planted on the ground, dealing with issues of land use and mining, in her pieces for the exhibition Beat. In a glass case intended for the display of precious jewelry, Luna places sugar molded into gem-like forms, underscoring the value of the ubiquitous crop to those that till the land. Ulat Panahon by Joven Mansit is a humorous socio-political commentary that reflects on the absurdity of the scandals that rock the nation. On the El Renacimiento, Mansit painted women in Maria Clara gowns gathered around a dining table, but with the food and plates floating above them and a severed hand hanging from the table. In another work, a washing machine is the object of interest around which have gathered a revolutionary soldier, a child with a leash around her neck, a woman wearing a baro't saya, a naked tribal man, and a manananggal.

Zean Cabangis' Goat Paths refers to the practically unrecognizable trail that hoarders use to navigate their homes. Intrigued by the links between desire, consumption, and acquisition shown in the TV series Hoarders, Cabangis paints 
a house filled to the brim with clutter, then masks it with colorful stripes, making reference to the layers upon layers of junk that are accumulated and stored.

Ryan Villamael draws from personal experience for both of his shortlisted exhibitions, Kosmik and Flatlands. The former was inspired by his encounters with different religions when he visited Bangkok and Singapore. Flatlands was inspired by his commute from his hometown in Laguna to Quezon City, which allowed him to observe the drastic change in atmosphere from relaxed province to energetic metropolis. He displays virtuosity in creating contemporary works though a very traditional craft-based medium. A single cutout covers an entire wall, and other oddly shaped pieces are assembled into an abstract rendition of a city.

Joey Cobobo's Lola 101 is a tribute to grandmothers as loving bearers of wisdom and family stories. The project involved interviewing grandmothers in their homes, then creating prints using leaves and plants gathered from the immediate surroundings. He transferred these portraits onto shifu paper. Each portrait is framed with lace crocheted by his mother, a detail which reinforces the feminine essence of the project.

The three winners of the 2013 Ateneo Art Awards drew from very personal experience to produce their exhibitions. Buen Calubayan's Fressie Capulong is an autobiographical work composed of personal artifacts—old photographs, paintings done in college, portraits of his mother, after whom the exhibition was titled. But the show is not in homage to those who have shaped his life; rather, it is the result of the artist's self-examination when he was at a crossroads in his career. In Raffy T. Napay's Thread Experience, there is no ambiguity about his feelings towards parents and siblings. In The Family, colorful threads that emanate from the heads of the mother and father connect family members to one another. It is a reflection of the love and affection for his family that Napay openly expresses. The photographs in Charles Buenconsejo's Reality is a Hologram include images of his wife and father, the stars, and the street. These seemingly unrelated images are united in their uncanny presentation. What appear to be shards of glass or ceramic on a cement pavement are, upon closer inspection, images of the cosmos.

The finalists and winners of the 2013 Ateneo Art Awards are evidence that the creative verve showcased in the Philippine art scene over the past ten years is undiminished.

Yael A. Buencamino Managing Curator Ateneo Art Gallery ybuencamino@ateneo.edu 


\section{Theater Productions IN Manila 2013}

KATY / Jan. 17-27, 2013 @ Tanghalang Aurelio Tolentino, Cultural Center of the Philippines (CCP); Jul. 25-Aug. 4, 2013 @ the Meralco Theater, Pasig

Dir: Nestor Torre. Spotlight Artists Centre.

A revival of the original Filipino musical on the life and times of the country's queen of jazz and bodabil, Katy De La Cruz.

BOEING BOEING / Jan. 25-Feb. 17, 2013 @ Onstage, Greenbelt 1, Makati Dir: Miguel Faustmann. Repertory Philippines.

Playboy Bernard juggles three fiancées_-all three of them flight attendants-but his juggling goes awry with the invention of the Boeing jet.

RIVALRY: ATENEO-LA SALLE THE MUSICAL / Jan. 25-Feb 17, 2013 @ Meralco Theater, Pasig

Dir: Jaime del Mundo. The 4th Wall Theatre Company.

Set in 1968, this original musical tells of the age-old rivalry between Ateneo and La Salle_-in basketball and in love.

THE KING OF THE BIRDS / Jan. 17-Feb. 2, 2013 @ Rizal Mini Theater, Ateneo de Manila University

Dir: Ron Capinding. Tanghalang Ateneo.

A philosophical fable inspired by a Persian poem, it tells of a nation of birds who embark on a journey to meet their one true King.

LABAW DONGGON / Jan. 29-Feb. 16, 2013 @ Cervini Field, Ateneo de Manila University

Dir: Jerry Respeto. Entablado.

An original musical adaptation of the Visayan epic Labaw Donggon, on the quest of the title's character to find three wives. 
THE KING AND I / Jan. 11-May 25, 2013 @ Newport Performing Arts Theater, Resorts World Manila

Dir: Freddie Santos. Resorts World Manila.

One of the most beloved classics in musical theater, this Rodgers and Hammerstein piece tells of a widowed English tutor who travels to Siam to teach Western culture to the many children of the king.

STAGES OF LOVE / Jan. 10-19, Feb. 5-9, 2013 @ Fine Arts Theater, Gonzaga Hall, Ateneo de Manila University

Dir: Cassie Manalastas and Georgia Uy. Ateneo Blue Repertory.

A musical review on the many stages of falling in and out of love.

D’WONDER TWINS OF BOAC / Feb. 1-Mar. 3, 2013 @ PETA-Phinma Theater, PETA Theater Center, New Manila

Dir: Maribel Legarda. Philippine Educational Theater Association (PETA).

An original musical adaptation of Shakespeare's Twelfth Night, set in Manila with the decline of the 1960s local movie industry.

IBALONG / Feb. 8-Mar. 3, 2013; Aug. 30-Sep. 15, 2013 @ Tanghalang Aurelio $\mathrm{V}$. Tolentino, CCP

Dir: Tuxqs Rutaquio. Tanghalang Pilipino.

An adaptation of the Bicolano epic, of warrior Handiong and his adventures.

THEY'RE PLAYING OUR SONG / Feb. 8-Mar. 3, 2013 @ Carlos P. Romulo Auditorium, RCBC Plaza, Makati

Dir: Robbie Guevara. 9Works Theatrical.

A musical comedy by Neil Simon where a top composer starts a collaboration with an up-and-coming lyricist; based on the real-life relationship of composer Marvin Hamlisch and Carole Bayer Sager.

COLLECTION / Feb. 13-Mar. 3, 2013 @ Wilfrido Ma. Guerrero Theater, 2/F Palma Hall, University of the Philippines (UP) Diliman

Dir: Dexter Santos. Dulaang UP.

A new original play by Floy Quintos, set in a Philippines where national treasures are up for sale. 
SPRING AWAKENING / Feb. 14-Mar. 1, 2013 @izal Mini Theater, Ateneo de Manila University

Dir: Andrei Pamintuan. Ateneo Blue Repertory.

A rock-musical adaptation by Steven Sater and Duncan Sheik of Frank Wedekind's play on the coming of age of teenagers met by conservatism and suppression by adults.

RED / Feb. 22-23, Mar. 1-2 @ CSB-SDA Theater, Manila; Aug 23-24@ Teatrino, Greenhills

Dir: Bart Guingona. Actors' Actors, Inc.'s The Necessary Theater.

A straight play by John Logan on the art theories and beliefs of the artist, Mark Rothko, brought to light by his fictional assistant, Ken.

NO WAY TO TREAT A LADY / Mar. 1-24, 2013 @ Onstage, Greenbelt 1, Makati

Dir: Audie Gemora. Repertory Philippines.

A dark musical set in 1970s New York, on a serial killer seeking fame and the NYPD detective hot on his trail.

PIAF / Mar. 8-23 , 2013 @ Carlos P. Romulo Auditorium, RCBC Plaza, Makati Dir: Bobby Garcia. Atlantis Productions.

Pam Gems's new version of her own work on the life and times of singer Edith Gassion, more popularly known as Edith Piaf, featuring over twenty-five of her most famous songs.

HIMALA: The 10 th Anniversary Celebration of the Musical / Mar. 15-23, 2013 @ PETA-Phinma Theater, PETA Theater Center, New Manila

Dir: Soxie Topacio. Touchworkx Group Inc. and the PETA Theater Center.

A concert version of the stage adaptation of the critically-acclaimed film about a woman who claims to be speaking to the Blessed Virgin.

THE GRADUATE / Apr. 5-28, 2013 @ Onstage, Greenbelt 1, Makati Dir: Jaime Del Mundo. Repertory Philippines.

A stage adaptation by Terry Johnson of the original novel and famous film, on a recent university graduate with no clear goals in his life, who is seduced by an older woman. 
THE FULL MONTY / Apr. 19-May 5, 2013 @ Carlos P. Romulo Auditorium, RCBC Plaza, Makati

Dir: Bobby Garcia. Atlantis Productions.

A fun musical based on the film, unemployed steelworkers decide to work as male strippers for some extra money, and they experience self-discovery and stronger friendships in the process.

SA WAKAS / Apr. 13-28, 2013 @ PETA-Phinma Theater, PETA Theater Center, New Manila

Dir: Andrei Pamintuan. Culture Shock Productions.

A new rock-musical featuring the songs of now-defunct band Sugarfree, on a love triangle and the choices that they make that define who they are.

TARZAN: THE MUSICAL / Jun. 14-29, 2013 @ Meralco Theater, Pasig Dir: Bobby Garcia. Atlantis Productions.

A musical based on the Disney film, with music by Phil Collins, about an orphan boy raised by a tribe of gorillas and how he becomes a man.

THE VIRGIN LABFEST / Jun. 26-Jul. 7, 2013 @ Tanghalang Huseng Batute, $\mathrm{CCP}$

The annual festival celebrating new works: all "untried, untested, unpublished and unstaged," from both emerging and established playwrights.

ROCK OF AGES / Jul. 12-28, 2013 @ Carlos P. Romulo Auditorium, RCBC Plaza, Makati

Dir: Chari Arespacochaga. Atlantis Productions.

A jukebox musical featuring songs from the 1980s about a small-town girl and a city rocker who fall in love in a famous rock club in Los Angeles.

SANDOSENANG SAPATOS / Jul. 13-21, 2013 @ Tanghalang Huseng Batute, $\mathrm{CCP}$

Dir: Tuxqs Rutaquio. Tanghalang Pilipino.

A wheelchair-bound young girl yearns to fulfill her father's wish of having a ballerina for a daughter, and dreams of a Shoe Fairy that grants her wish on her birthdaybut only in her dreams. 
ADARNA / Jul. 17-Aug. 1, 2013 @ Wilfrido Ma. Guerrero Theater, 2/F Palma Hall, UP Diliman

Dir: Jose Estrella. Dulaang UP.

Based on the Filipino corrido Ibong Adarna, of three princes and their adventures beginning with their search for the Adarna bird whose song would cure their sick father.

A NEW BRAIN/ Jul. 24-Aug. 10, 2013 @ Fine Arts Theater, Gonzaga Hall, Ateneo de Manila University

Dir: Toff de Venecia. Ateneo Blue Repertory.

Musical by William Finn, of a composer who is diagnosed with a rare medical condition that sends him into a coma and may end his life.

ALICE IN WONDERLAND / Aug. 17-Dec. 15, 2013 @ Onstage, Greenbelt 1, Makati

Dir: Joy Virata. Repertory Philippines' Theater for Young Audiences.

An adaptation of Lewis Carroll's Alice's Adventures in Wonderland, where young Alice falls down a rabbit hole into a fantasy world.

FLORANTE AT LAURA / Aug. 1-18, 2013 @ Cinema 3 SM Southmall / Star Theater / AFP Theater, Camp Aguinaldo

Dir: Roeder Camañag. Gantimpala Theater Foundation.

The metrical romance by Francisco Baltazar, Florante at Laura, here presented as a komedya, of the love story of Duke Florante and Princess Laura who is also being pursued by Count Adolfo.

KATIPUNAN NG MGA ANAKNG BAYAN / Aug. 15-Oct. 20, 2013 (Touring Company)

Dir: Joel Lamangan and Jun F. Flavier Pablo. Gantimpala Theater Foundation. A musical based on the life of Andres Bonifacio.

ANG PRINSIPE AT ANG PULUBI / Aug. 8-Oct. 5, 2013 (Touring Company) Dir: Gean Allain De Leon. Gantimpala Theater Foundation.

A musical for children based on Mark Twain's The Prince and the Pauper. 
PAMANA / Aug. 21-24, 2013 @ Meralco Theater, Pasig

Dir: Maribel Legarda. Ninoy and Cory Aquino Foundation, Inc.

Three generations of a family relate their lives in the context of the historical developments of the country, from when Ninoy Aquino died to the present time.

ANG BUHAY AY PELIKULA / Aug. 13-31, 2013 @izal Mini Theater, Ateneo De Manila University

Dir: Jethro Tenorio. Entablado.

Dennis Marasigan's Palanca Award-winning play which parallels the Philippine movie industry to real life.

LOVE: THIS IS NOT YET A MUSICAL / Aug. 23-Sep. 1, 2013 @ 79 Ermin Garcia St., Brgy Pinagkaisahan, Cubao, Quezon City

Sipat Lawin Ensemble.

A communal event where both artists and audiences take part; about how love is felt, heard, seen, experienced, perceived, and manifested.

KANSER: NOLI ME TANGERE / Aug. 30-Sep. 13, 2013 @ AFP Theater, Camp Aguinaldo / Star Theater, Star City Compound / Cinema 3, SM Southmall Dir: Roobak Valle. Gantimpala Theater Foundation.

A musical adaptation of Jose Rizal's famous novel.

BATANG RIZAL / Aug. 16-Sep. 1, 2013 @ PETA-Phinma Theater, PETA Theater Center, New Manila

Dir: Dudz Teraña. Philippine Educational Theater Association (PETA).

A musical about a young boy who travels back to the late nineteenth century in Calamba, Laguna, and meets Jose Rizal at the time of his childhood.

LORENZO / Sep. 5-14, 2013 @ CSB-SDA Theater, Manila

Dir: Nonon Padilla. Green Wings Entertainment.

A new contemporary opera on the events in the life of the first Filipino saint, Lorenzo

Ruiz, from when he accidentally joins a group of missionaries going to Japan. 
MIND’S EYE / Sep. 6-8, 2013 @ Carlos P. Romulo Auditorium, RCBC Plaza, Makati

Dir: Jaime Del Mundo. C. Virata Advisory and Gillian Joyce Virata.

A theatrical adaptation of Paul Fleischman's award-winning novel, which tells how a friendship develops between an old lady and her hospital roommate, a young lady who had just been in a riding accident.

THE DUCHESS OF MALFI or ANG DUKESA NG MALFI / Sep. 11-29, $2013 @$ Wilfrido Ma. Guerrero Theater, 2/F Palma Hall, UP Diliman

Dir: Tony Mabesa. Dulaang UP.

The classic by John Webster, with shows in English and in Filipino as translated by Allan Palileo, on a tragic story loosely based on events in the life of an Italian duchess in the 1500 s.

GENESIS / Sep. 11-21, 2013 @ Rizal Mini Theater, Ateneo de Manila University Dir: Francis Matheu. Ateneo Blue Repertory.

Based on Stephen Schwartz's Children of Eden, Genesis presents a different take on some of the most famous stories in the Bible.

ANG BAKKHAI / Sep. 12-21, 2013 @ The Black Box, Fine Arts Annex, Ateneo de Manila University

Dir: JK Anicoche. Tanghalang Ateneo.

An adaptation in Filipino of classic Greek tragedy, The Bacchae by Euripides.

CARRIE / Sep. 20-Oct. 6, 2013 @ Carlos P. Romulo Auditorium, RCBC Plaza, Makati

Dir: Bobby Garcia. Atlantis Productions.

A musical based on Stephen King's bestselling novel about a teenage girl who has supernatural powers and her overprotective mother.

THE BLUEBIRD OF HAPPINESS / Sep. 26-Oct. 20, 2013 @ Meralco Theater, Pasig

Dir: Jaime Del Mundo. Trumpets, Inc.

A brand-new musical adaptation of the play The Bluebird by Belgian playwright Maurice Maeterlinck, about two poor and unhappy children who search for the mythical Bluebird of Happiness. 
DER KAUFFMAN / Sep. 27-Oct. 13, $2013 @$ Tanghalang Huseng Batute, CCP Dir: Tuxqs Rutaquio and Rody Vera. Tanghalang Pilipino.

An adaptation by Rody Vera of Shakespeare's The Merchant of Venice, set in Nazi Germany, using the Tagalog translation by Rolando Tinio.

IBONG ADARNA / Sep. 27-Oct. 13, 2013 @ AFP Theater, Camp Aguinaldo / Cinema 3, SM Southmall / Star Theater, Star City Compound

Dir: Roobak Valle. Gantimpala Theater Foundation.

A more traditional presentation of the classic corrido Ibong Adarna.

CINDERELLA / Oct. 9-Dec. 29, 2013 @ Newport Performing Arts Theater, Resorts World Manila

Dir: Michael Williams. Resorts World Manila.

The beloved fairytale of a girl and a glass slipper, with music by the Rodgers and Hammerstein tandem.

CLOSER / Oct. 4-27, 2013 @ Whitespace, Chino Roces Ext., Makati

Dir: Ana Abad-Santos. Red Turnip Theater.

Olivier Award-winning play on four people trading partners in search of love and lust.

GREASE / Nov. 9-Dec. 1, 2013 @ Carlos P. Romulo Auditorium, RCBC Plaza, Makati

Dir: Robbie Guevara. 9Works Theatricals.

A musical set in the 1950s following the lives of working-class teenagers in high school as they go through love and graduation.

MAXIE THE MUSICAL / Nov. 9-Dec. 8, 2013 @ PETA-Phinma Theater, PETA Theater Center, New Manila

Dir: Dexter Santos. Bit by Bit Productions.

A musical on the coming-of-age of a gay teen, based on the screenplay and film, Ang Pagdadalaga ni Maximo Oliveros. 
THE ADDAMS FAMILY/ Nov. 15-Dec. 1, 2013 @ Meralco Theater, Pasig Dir: Bobby Garcia. Atlantis Productions.

A musical comedy based on the single-panel gag cartoons by Charles Addams, about an American family with an affinity for the macabre, now dealing with the Addams daughter falling in love with a normal boy.

THE PRODUCERS / Nov. 15-Dec. 15, 2013 @ Onstage, Greenbelt 1, Makati Dir: Jaime del Mundo. Repertory Philippines.

Tony Award-winning musical about a down-on-his-luck Broadway producer and his accountant and their scheme to produce a flop.

EL FILIBUSTERISMO / Nov. 15-29, 2013 @ AFP Theater, Camp Aguinaldo / Star Theater, Star City Compound / Cinema 3, SM Southmall

Dir: Jeffrey Camañag. Gantimpala Theater Foundation.

A musical adaptation of the novel by the National Hero, Jose Rizal.

SUGOD, FILEMON MAMON! / Nov. 19-30, 2013 @ Rizal Mini Theater, Ateneo De Manila University

Dir: JJ Ignacio. Ateneo Entablado.

An adaptation of a children's book about an overweight child who wants to be cast as Andres Bonifacio in their school play, but is cast as the villain instead.

TEATRO PORVENIR / Nov. 20-Dec. 8, 2013 @ Wilfrido Ma. Guerrero Theater, 2/F Palma Hall, UP Diliman

Dir: Alex Cortez. Dulaang UP.

This Palanca Award-winner is a new interpretation on the lives and times of Andres Bonifacio, Macario Sakay and Aurelio Tolentino, and the history of the Katipunan.

SAN ANDRES B. / Nov. 29-Dec. 8, 2013 @ Tanghalang Aurelio V. Tolentino, CCP

Dir: Floy Quintos. Tanghalang Pilipino.

A modern opera on the life, loves, successes, and failures of Andres Bonifacio.

Kyla Halili Rivera

Freelance Actor kylarivera@gmail.com 